\title{
Coliform Bacteria, Lactose Fermenting
}

National Cancer Institute

\section{Source}

National Cancer Institute. Coliform Bacteria, Lactose Fermenting. NCI Thesaurus. Code C122267.

Any rod-shaped, gram-negative, non-spore forming bacteria that is capable of fermenting lactose to produce acid and gas. 